\title{
EVALUASI PELAKSANAAN PROGRAM LATIHAN SENAM DI KLUB SENAM SEMEN PADANG
}

\author{
Pitnawati $^{1}$, Damrah ${ }^{2}$ \\ Program Studi Pendidikan Jasmani Kesehatan dan Rekreasi, Fakultas Ilmu Keolahragaan, Universitas \\ Negeri Padang. Jalan Prof. Dr. Hamka Air Tawar Barat, Padang, 25132, Indonesia \\ Email.pitnawati@yahoo.co.id ${ }^{1}$, damrahburhan@yahoo.co.id ${ }^{2}$
}

\begin{abstract}
Belum berjalannya program latihan senam di Klub Senam Semen Padang merupakan masalah yang perlu dicarikan solusi pemecahannya. Tujuan penelitian ini adalah untuk mendapatkan informasi yang akurat dan objektif yang dapat dijadikan pertimbangan dalam menentukan pelaksanaan program latihan senam yang telah dilakukan, apakah program latihan tersebut dapat dilanjutkan, atau harus diperbaiki, dan bahkan bisa di sebarluaskan ke klub atau daerah lain. Sekaligus membantu pertanggung jawaban serta peningkatan pemahaman terhadap fenomena yang terjadi. Metode penelitian yang digunakan adalah pendekatan evaluasi dengan menggunakan model CIPP yang dikembangkan oleh Stufflebeam yaitu model evaluasi dengan mengamati dari sudut konteks (context), masukan (input), proses (prosess) dan hasil (product). Hasil evaluasi program latihan dengan menggunakan model CIPP adalah program latihan senam belum berjalan secara optimal dan perlu perbaikan di beberapa aspek, yaitu peningkatan perhatian dari pengelola (FKSSP) terhadap kebijakan yang telah dikeluarkan, perbaikan terhadap criteria rekruitmen pelatih dan atlet secara professional, perbaikan dan pengadaan sarana prasarana yang bertaraf nasional/internasional, menggunakan metode latihan yang bervariasi dan tidak membosankan, peningkatan asupan gizi atlet sesuai dengan kebutuhan kalori, peningkatan system pengawasan yang terpadu serta peningkatan kesejahteraan pelatih dan atlet. Semua kebutuhan ini tidak lain adalah untuk melanjutkan proses pelatihan dalam rangka mendapatkan peningkatan prestasi yang optimal ditingkat daerah, nasional dan internasional. Oleh karena itu, jika pelaksanaan program latihan senam Semen Padang dapat berjalan dengan baik dan tetap dilanjutkan, maka komponen-kompenen yang telah disampaikan di atas perlu diperbaiki dan direvisi, agar kegiatan senam dapat berprestasi dengan baik.
\end{abstract}

Kata kunci : Evaluasi Program, Senam, Model CIPP.

\section{EVALUATION OF GYMNASTIC TRAINING PROGRAM IMPLEMENTATION IN SEMEN PADANG GYMNASTIC CLUB}

\begin{abstract}
The issue of this study is the implementation of gymnastic training program that does not run well so that proper solution to solve this problem is demanded. The purpose of this study is to obtain accurate and objective information which can be taken into consideration in determining the implementation of the gymnastics training program that has been carried out, whether the training program can be continued, or must be revised, and can even be expanded to other clubs or regions. At the same time, it helps accountability and increases understanding of the phenomena that occur recently. This study employed an evaluation approach using the CIPP model developed by Stufflebeam, i.e. the evaluation model that observed the context, input, process and results (product). The results of this study showed that the gymnastics training program has not run optimally and needed improvement in several aspects, namely the increase of attention from the manager (FKSSP) to the policies that have been issued, improvement in the criteria for professional recruitment of trainers and athletes, improvement and procurement of national / international standard facilities, the
\end{abstract}


use of varied training methods, increase of athletes' nutritional intake according to caloric needs, improvement of integrated monitoring systems and improvement of the welfare of trainers and athletes. All of these needs are none other than to continue the training process in order to obtain optimal performance improvements at the regional, national and international levels. Therefore, if the implementation of gymnastic training program runs well, then the components mentioned above need to be repaired and revised, so that gymnastic activities can perform well.

Key words : Program Evaluation, Gymnastic, CIPP Model.

\section{PENDAHULUAN}

Untuk mencapai tujuan prestasi olahraga, diperlukan usaha-usaha yang krieatif dan hal ini terungkap dalam Undang-Undang No.3 tahun 2005 tentang Sistem Keolahragaan Nasional, pada pasal 1 ayat 13 yang berbunyi bahwa, "Olahraga prestasi adalah olahraga yang membina dan mengembangkan olahragawan secara terencana, berjenjang, dan berkelanjutan melalui kompetisi untuk mencapai prestasi dengan dukungan ilmu pengetahuan dan teknologi keolahragaan". Terlepas dari penjabaran di atas Syafruddin (2013:18) menjelaskan bahwa yang dimaksud dengan "prestasi dalam olahraga adalah hasil yang diperoleh atau dicapai oleh seseorang melalui kegiatan olahraga atau berolahraga. Dan hasil yang dimaksud terlihat dalam bentuk kemampuan (ability) fisik dan keterampilan (skill) motorik atau teknik serta kemampuan mental seseorang atau atlet dalam berolahraga." Dan terkait itu Syafruddin (2013:55) juga menjelaskan "kemampuan seseorang atau atlet dalam suatu pertandingan atau kompetisi pada dasarnya ditentukan oleh empat faktor yaitu kondisi fisik, teknik, taktik, dan mental". Untuk membuat seorang atlet bisa menguasai empat faktor di atas maka bisa diasah melalui latihan. Latihan-latihan yang diberikan harus mencakup empat faktor tersebut. Begitu juga untuk latihan senam artistik.

Olahraga Senam merupakan gerakan yang menggabungkan aspek tumbling dan akrobatik yang mendapatkan efek artistik dari gerakangerakan yang dilakukan pada senam lantai, meja lompat, balok keseimbangan, palang bertingkat, palang sejajar, palang tunggal, ring, dan kuda pelana. Aspek tumbling yaitu gerakan yang cepat dan eksplosif dan merupakan gerak yang pada umumnya dirangkaikan pada suatu garis lurus. Sedangkan akrobatik adalah keterampilan yang pada umumnya menonjolkan fleksibilitas gerak dan keseimbangan. Dari pernyataan di atas, bahwa seseorang atlet senam akan dapat dikatakan berprestasi, jika mempunyai kemampuan penguasaan terhadap teknik, taktik dan mental yang seimbang. Selain itu, prestasi terbaik atlet senam merupakan hasil pembinaan dan latihan yang diberikan kepada atlet melalui latihan dan kompetisi yang terprogram dengan baik dan terarah. Pencapaian prestasi terbaik atlet senam ditentukan dan dipengaruhi oleh banyak faktor yang secara garis besar dapat dikelompokkan atas dua faktor, yaitu faktor internal yaitu yang berasal dari dalam diri atlet seperti fisik, teknik, intelegensi, dan kepribadiannya dan juga faktor eksternal seperti sarana prasarana, kualifikasi pelatih, pengalaman pelatih dan juga system rekrutment.

Klub senam Semen Padang merupakan salah satu pusat pembinaan olahraga senam yang memiliki visi, yaitu unggul dan dapat membawa nama baik PT. Semen Padang ke tingkat nasional dan internasional. Klub senam Semen Padang ini telah ada sejak tahun 1996 dan telah menghasilkan banyak prestasi seperti Syaiful nazar dan Riri Wulandari, keduanya telah memiliki pengalaman nasional dan internasional. Artinya dengan fasilitas yang cukup memadai dan didukung oleh program latihan yang berjenjang dan berkesinambungan, telah mampu menunjukkan perkembangan yang cukup signifikan.

Atlet melakukan latihan pada setiap pagi hari pada pukul 05.00 sampai pukul 06.00 subuh dan sore hari sepulang sekolah. Jadwal latihan yang ditetapkan oleh pelatih disesuaikan dengan kondisi atlet. Di Klub senam Semen Padang terdiri dari atlet-atlet usia dini dan atlet daerah yang memiliki prestasi dan kemampuan yang yang cukup baik. Sehingga jika daerah membutuhkan, maka atlet tersebut akan kembali ke daerahnya masing-masing. namun secara umum, atlet tersebut dipersiapkan untuk mengikuti perlombaan di tingkat daerah maupun di tingkat nasional.

Pada tahun 2003 Klub Senam Semen Padang mulai mendatangkan pelatih nasional Sutrisno yang dulunya mantan atlet senam nasional menjadi pelatih senam di Klub senam 
Semen Padang hingga sekarang. Peningkatan prestasi atlet senam ini terus mengalami kemajuan, dan ini dibuktikan dengan banyaknya atlet yang bisa lolos ke PON dan mampu memperoleh medali pada PON 2004 sampai PON 2016. Prestasi terbaik diperoleh melalui pesenam nasional dari Sumatera Barat Riri Wulandari dengan memperoleh medali emas pada Sea Games di Manila tahun 2005. Namun pada PON 2016 Atlet senam Semen Padang hanya mampu memperoleh medali perunggu pada meja lompat dan khusus untuk senam belum memperoleh medali. Ini merupakan salah satu fakta empiris yang menggambarkan masih rendahnya prestasi atlet senam Klub senam Semen Padang. Tentu hal ini menjadi permasalahan bagi kita semua, sehingga timbul pertanyaan bagaimana prestasi pesenam Semen Padang saat ini. Mungkin banyak faktor yang menyebabkan masalah tersebut. Berdasarkan permasalahan di atas, bahwa aspek pembinaan tidak akan terlepas dari pelaksanaan program latihan. Untuk menilai dan mengambil kesimpulan pelaksanaan latihan yang telah dilakukan apakah bisa dilanjutkan, atau harus diperbaiki, dan bahkan bisa di sebarluaskan, oleh karena itu perlu di lakukan evaluasi.

Menurut Harsono (2001:43) "latihan atau training adalah suatu proses latihan yang sistematis yang dilakukan secara berulang-ulang, yang kian hari jumlah beban latihannya kian bertambah". Pendapat tersebut menjelaskan bahwa untuk mencapai hasil yang maksimal, latihan harus dilakukan secara sistematis dalam waktu yang panjang dan dilaksanakan secara berulang-ulang dengan beban yang makin meningkat sesuai dengan cabang olahraga yang ditekuni. Tercapainya tujuan perencanaan latihan yang diinginkan maka latihan harus direncanakan dan dibangun dengan logis serta dilakukan melalui tahapan yang berjenjang. Perkembangan ilmu pengetahuan dan pemikiran manusia yang semakin lama semakin maju, akan memaksa pula untuk merencanakan program latihan yang seimbang. Program yang dibuat dengan berdasarkan ilmu pengetahuan adalah sangat membantu dan besar manfaatnya bagi peningkatan prestasi olahraga. Untuk pemberian program latihannya disesuaikan dengan teori dan prinsip latihan cabang olahraganya masingmasing. Penyusunan dan pelaksanaan dari program latihan inilah salah satu faktor pendukung peningkatan prestasi atlet senam, agar bisa mengetahui sejauh mana keberhasilan dari program yang telah di tetapkan dan dilaksanakan. Untuk itu diperlukan evaluasi terhadap program latihan yang telah dilaksanakan.

Dalam melakukan evaluasi, peneliti menggunakan model evaluasi CIPP, yaitu model evaluasi dengan mengamati dari sudut konteks, input, proses dan produks. Model Evaluasi CIPP memiliki beberapa kelebihan, antara lain adalah lebih komprehensif karena objek evaluasi bukan hanya hasil, tetapi juga mencakup konteks, masukan, proses, maupun hasil. Tidak seperti kebanyakan pendekatan evaluasi yang lain, model CIPP mengkaji tidak hanya sebuah enterprise hasil di lingkungan, tetapi juga pada rencana, tujuan, sumber daya dan pelaksanaannya (Stufflebeam 2017:6). Dengan demikian evaluasi model CIPP dapat mengatasi masalah guna mengetahui sebab-sebabnya serta dapat membantu mencari solusi. Karena model evaluasi CIPP ini menurut peneliti sangat relevan dengan objek penelitian dan dapat mengkaji masalah secara menyeluruh. Di samping itu keunggulan lain model CIPP adalah memiliki pendekatan yang holistik dalam evaluasi, dengan tujuan memberikan gambaran yang sangat detail dan luas terhadap suatu proyek atau kegiatan, mulai dari konteksnya hingga saat proses implementasi.

\section{METODE}

Metode yang digunakan dalam penelitian ini adalah evaluasi dengan menggunakan model CIPP (Context, Input, Process, Product). Penggunaan model CIPP di pilih karena model ini merupakan model evaluasi program, sehingga dapat dipakai dalam mengevaluasi pelaksanaan latihan atlet senam Semen Padang secara lengkap mulai dari persiapan sampai dengan prestasi yang dicapai. Evaluasi konteks digunakan untuk mengidentifikasi dan menilai kebutuhan, problem, aset yang mendasari disusunnya suatu program. Evaluasi input dilakukan untuk membantu para pengambil keputusan menilai alternatif, rencana tindakan, rencana dan anggaran untuk memenuhi kebutuhan dan tujuan yang ditargetkan. Evaluasi proses dilakukan untuk membantu mengimplementasikan keputusan sampai sejauh mana rencana telah diterapkan. Evaluasi produk yaitu berupaya untuk mengidentifikasi dan mengakses keluaran dan manfaat, baik yang direncanakan untuk jangka pendek maupun jangka panjang. 
Penelitian ini dilakukan dengan mendeskripsikan pelaksanaan program latihan yang dilakukan di Klub senam Semen Padang, kemudian dievaluasi dengan membandingkan apa yang telah dicapai dari program peningkatan prestasi atlet dengan apa yang seharusnya dicapai berdasarkan standar yang telah ditetapkan. Adapun disain evaluasi program yang digunakan adalah sebagai berikut:
Setelah itu baru dilanjutkan dengan penarikan kesimpulan atau verifikasi, yaitu untuk mencari pola tema atau hal-hal yang sering muncul, sehingga diperoleh suatu kesimpulan yang semakin lama menjadi semakin jelas seiring dengan semakin banyaknya data yang diperoleh.

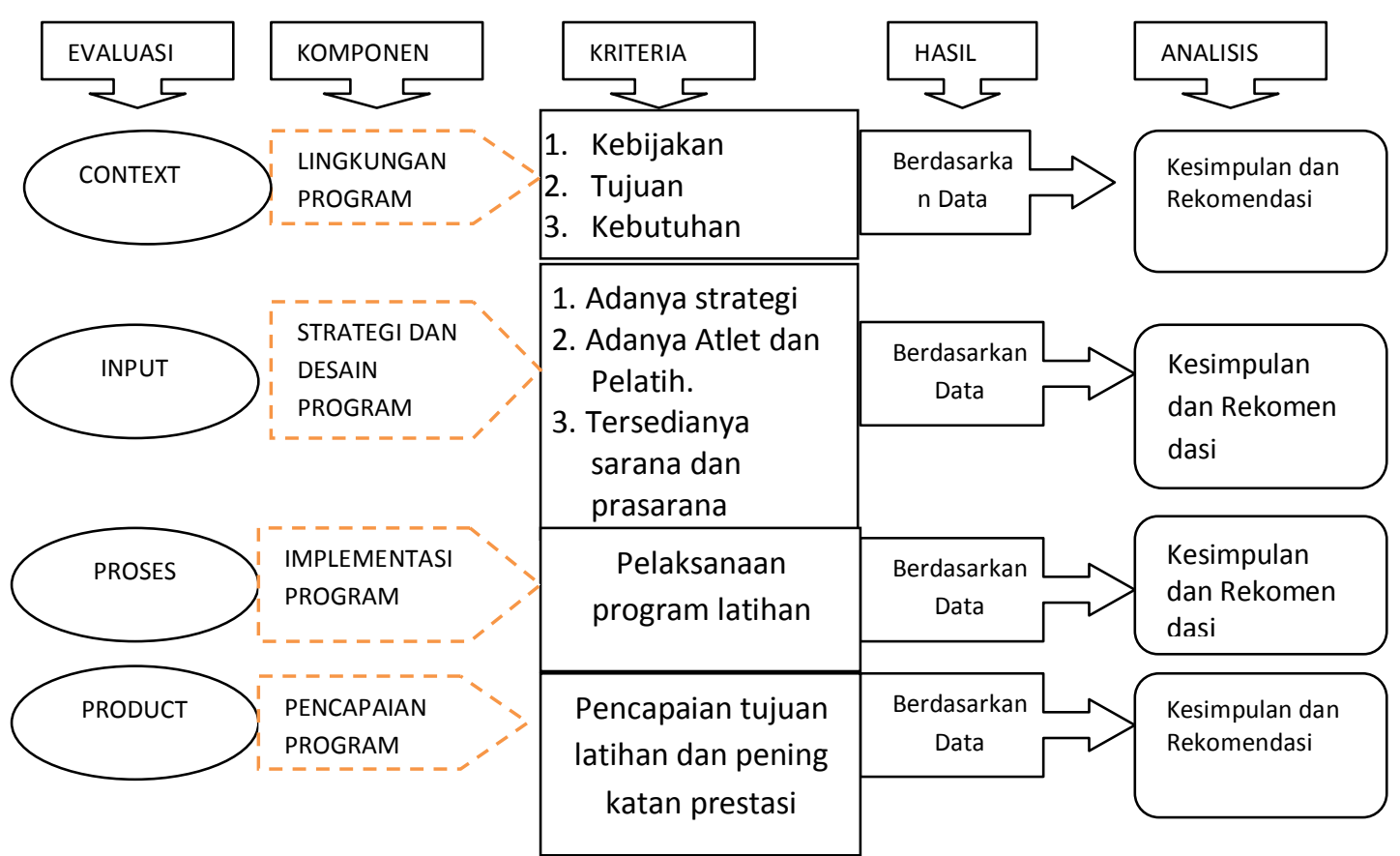

Gambar 1.Disain Evaluasi Model CIPP

Instrumen yang digunakan untuk penelitian ini adalah wawancara, observasi dan dokumentasi serta dianalisis dengan beberapa tahapan, pertama melakukan reduksi data, yaitu dengan kondisi data yang diperoleh dari lapangan yang tidak terbatas, sehingga peneliti perlu melakukan reduksi. Hal ini dimaksudkan untuk hal-hal pokok serta tema-tema yang relevan dengan fokus penelitian.

Setelah proses ini dilakukan, maka dilanjutkan dengan penyajian data, yaitu dalam bentuk uraian singkat dan jelas, dengan didukung oleh bagan, diagram yang berhubungan dengan kategori dan sejenisnya.

Tujuan dari penyajian data ini adalah memudahkan untuk memahami apa yang terjadi di lapangan dan merencanakan kerja selanjutnya berdasarkan apa yang telah dipahami tersebut dan memungkinkan data hasil penelitian tidak tercampur dengan sejumlah data yang belum diolah.

\section{HASIL}

\section{Hasil Evaluasi Pelaksanaan Program Latihan Senam Semen Padang ditinjau dari komponen Konteks}

Evaluasi konteks mengenai dasar pembuatan program latihan di Klub Senam Semen Padang pada dasarnya kegiatan senam menyesuaikan dengan visi dan misi serta tujuan dari klub senam Semen Padang, yaitu menjadi pusat pembinaan olahraga senam untuk mengembangkan minat, bakat dan budaya masyarakat dalam melahirkan atlet-atlet yang berkualitas.

Misinya adalah mencari dan membina bibit-bibit atlet, menumbuh kembangkan sikap mental, disiplin, kerjasama dan motivasi berlatih yang optimal dan berusaha unggul dalam setiap pertandingan atau perlombaan. Klub Senam Semen Padang melakukan pembinaan dengan tujuan menghasilkan atlet-atlet yang mampu 
bersaing di tingkat Nasional maupun Internasional.

Suatu prestasi yang tinggi tidak akan dapat dicapai kecuali dengan latihan dan kerja keras. Latihan tidak akan berjalan baik tanpa adanya program latihan yang baik. Program latihan senam ini disesuaikan dengan tingkat kemampuan atlet. Diantara faktor yang menjadi patokannya adalah lamanya atlet tersebut latihan, sampai dimana kemampuannya baik dari segi fisik, maupun teknik. Tujuan pelaksanaan program latihan di Klub Senam Semen Padang adalah meningkatkan kemampuan fisik, teknik dan keterampilan gerak.

Semua program ini mendapatkan dukungan dari pengurus, serta para atlet dan orang tua mereka masing-masing, sehingga latihan dapat berjalan lancar. Latihan disesuaikan dengan target yang ditentukan pelatih kepada tiap-tiap atlet.

Dengan tujuan adalah peningkatan kualitas gerakan atlet. Terkait dengan analisis kebutuhan dalam membuat program, terdapat perbedaan antara program atlet putra dengan atlit putri, termasuk penggunaan nomor senamnya.

Untuk putri nomor yang dilatih disesuaikan dengan nomor perlombaan, yaitu nomor lantai, meja lompat, balok keseimbangan, dan palang bertingkat. Untuk putra ada nomor meja lompat, lantai, palang sejajar, palang tunggal, ring dan pomel.

Semua kebijakan untuk menjalankan kegiatan latihan diatur dan dijalankan oleh pelatih berdasarkan persetujuan pengelola yaitu FKKSP (Forum Komunikasi Karayawan Semen Padang), sehingga semua yang terkait dengan kebutuhan, yaitu sarana dan prasarana latihan, keuangan, makanan dan gizi dapat terpenuhi dengan baik.

Hal-hal yang belum dimiliki seperti lantai yang panjangnya $12 \times 12$ sesuai dengan standar, dilakukan dengan cara modifikasi, yaitu memanfaatkan fasilitas yang sudah ada sambil menunggu perbaikan dan pengadaan lapangan yang standar.

\section{Evaluasi Pelaksanaan Program Latihan Senam Semen Padang ditinjau dari komponen Input}

Dalam penelitian ini, evaluasi input meliputi pengurus, pelatih, atlet, dan sarana prasarana yang mendukung pelaksanaan program latihan, dalam rangka pencapaian prestasi yang optimal. Kelayakan dan kualifikasi pelatih dan atlet senam Semen Padang cukup baik, baik dari segi kondisi fisik, teknik, taktik maupun mental.

Pelatih dan atlet sudah memiliki pengalaman yang cukup baik di tingkat nasional dan internasional seperti PON dan Asean School. Semua atlet senior baik putra maupun putri sudah pernah mengikuti perlombaan daerah dan PON. Sedangkan atlet yunior dengan jumlah lebih kurang 20 orang merupakan atlet yang disiapkan untuk lapisan kedua dan ketiga.

Semua atlet ini didampingi oleh 2 orang pelatih dan 2 orang asisten yang telah ditugaskan oleh pengurus senam Semen Padang (FKKSP). Rata-rata atlet masih berada di sekolahan (SD, SMP dan SMA) dan hanya 4 atlet yang sedang mengikuti pendidikan tinggi yaitu di bidang keolahragaan, sehingga diharapkan jika mereka sudah melanjutkan pendidikan ditingkat Universitas atau atau dibidang keolahragaan akan membuat mereka menjadi lebih dewasa baik dalam berpikir maupun dalam berbuat serta bertingkah laku.

Sementara untuk kualifikasi pelatih senam Semen Padang sudah memiliki kualitas yang baik, mereka sudah memiliki sertifikat pelatih nasional dan berpendidikan sarjana. Seiring dengan itu, pengurus yang bertanggung jawab dalam bidang senam di Semen Padang ini adalah FKKSP dan dibantu oleh pengurus senam (Persani) Sumatera Barat.

Semua unsure pengurus ini telah memberikan dukungan terhadap pelaksanaan program latihan, namun belum maksimal. Beberapa fasilitas yang tersedia untuk mendukung latihan senam ini sudah cukup memadai untuk semua nomor, kecuali alat bantu kolam busa yang masih sangat minim, dan atlet merasa kurang nyaman dengan keadaan kolam busa tersebut, termasuk luas lantai yang masih kurang dari 12 x 12 meter (ukuran standar) yang tersedia baru $10 \times 10$ meter.

Untuk itu pelatih maupun atlet masih sangat berharap pengurus dapat memenuhi segala kekurangan alat-alat ini.

\section{Evaluasi Pelaksanaan Program Latihan Senam Semen Padang ditinjau dari komponen Proses}

Evaluasi process meliputi aspek persiapan, pelaksanaan dan pengawasan dari program latihan yang dilakukan. Persiapan latihan terdiri dari fasilitas yang digunakan oleh 
pelatih dan atlet selama latihan berlangsung, termasuk pemanasan. Semua kegiatan persiapan, rata-rata dapat berjalan dengan cukup baik sesuai dengan criteria yang di evaluasi.

Beberapa kegiatan yang kurang terlihat adalah variasi pemanasan yang kurang menarik dan cendrung menoton serta kurang diberikan koreksi terhadap beberapa kesalahan yang dilakukan atlet, seperti perbaikan kualitas gerakan yang kurang sempurna dan kerja sama tim. Hal ini sangat penting untuk mempertajam proses latihan yang berkualitas. Memperhatikan dan mengoreksi kesalahan merupakan bagian yang sangat penting bagi seorang pelatih dan atlet.

Begitupun terhadap pelaksanaan latihan yang diberikan kepada atlet meliputi aspek tehnik, phisik, mental dan social. Aspek tehnik terdiri dari aspek yang dibutuhkan dalam senam, yaitu keindahan, keluasan, kerapian, kedinamisan dan tingkat kesulitan. Semua unsure ini dilakukan sesuai dengan tingkat kemampuan gerak masing-masing yang mengarah pada standar nasional/ internasional.

Aspek fisik terdiri dari kecepatan, kordinasi, kelenturan, daya tahan, dan kelincahan. Aspek ini dilakukan secara komprehensif dan dinamis. Pelatih secara bertahap memperbaiki segala kekurangan sesuai dengan unsure- unsure yang dibutuhkan.

Namun criteria yang diharapkan tidak di tulis secara jelas dan hanya dilakukan secara verbal. Hal yang tradisional ini perlu menjadi perhatian yang serius bagi pengurus dan pelatih, sehingga atlet dapat terperhatikan secara maksimal.

Sedangkan untuk latihan mental dilakukan melalui kriteria penilaian dan penghargaan yang diberikan kepada atlet yang telah mencapai kriteria yang diberikan pelatih. Di samping itu pelatih juga memberikan kesempatan kepada setiap atlet untuk mengikuti perlombaan di daerah maupun luar daerah seperti Porkot, Porprov, kejurwil dan kejurnas.

Atlet merupakan objek yang menjadi faktor yang berpengaruh terhadap berhasil tidaknya suatu cabang olahraga dapat berprestasi dan merupakan hal yang mutlak dan harus dimiliki oleh suatu cabang olahraga termasuk senam artistik, sehingga dapat mencapai prestasi yang optimal. Kenyamanan atlet dalam mengikuti program latihan senam artistik yang diberikan oleh pelatih menjadi kunci sukses keberhasilan atlet.
Oleh karena itu pengamanan atlet ini perlu ditingkatkan, sehingga atlet merasa aman, nyaman dan percaya diri untuk melakukan latihan. Seiring dengan itu kendala lain adalah pelatih sering datang terlambat, di sebabkan karena pelatih senam ini merupakan pegawai di Dispora Provinsi dan memiliki jarak yang cukup jauh ke lokasi latihan. Walaupun demikian kegiatan latihan masih tetap berjalan sesuai dengan waktu yang ditentukan karena dibantu oleh asisten pelatih.

\section{Evaluasi Pelaksanaan Program Latihan Senam Semen Padang ditinjau dari komponen Product}

Evaluasi product yang pertama yaitu prestasi yang dicapai Klub Senam Semen Padang ditingkat PORPROV sangat memuaskan. Secara keseluruhan untuk juara All Round Klub Senam Semen Padang selalu meraih medali emas. Tetapi untuk hasil pertandingan seperti PON yang rata-rata banyak diwakili oleh atlet dari klub senam Semen Padang, belum mampu mendapatkan hasil yang terbaik.

Pada PON 2016 yang lalu, atlet yang berhasil lolos PON dari klub senam Semen Padang ada 8 orang tapi hanya 1 orang yang bisa meraih medali perunggu. Kondisi ini berarti bahwa program latihan yang telah disusun pelatih selama ini, masih belum berhasil dan perlu dilakukan perbaikan-perbaikan di semua lini, mulai dari penataan dan regulasi untuk pengurus, pelatih dan atlet, kesesuaikan program latihan dengan kebutuhan dan kemampuan atlet, pengadaan sarana prasarana yang berstandar nasional, metode latihan yang berdasarkan pada Ipsteks serta keterlibatan pelatih dan atlet dalam mengikuti beberapa perlombaan di tingkat daerah, wilayah, nasional dan internasional perlu ditingkatkan.

Semua ini tak lain adalah untuk mendapatkan hasil yang lebih baik dan berkualitas. Dengan demikian dapat disimpulan bahwa pelatihan senam klub senam FKSSP dapat dilanjutkan dengan beberapa perbaikan di bidang konteks, input, proses dan outputnya sebagai yang dijelaskan di atas.

\section{DAFTAR RUJUKAN}

Achmad Sofyan Hanif. 2011. "Evaluasi Terhadap Sekolah Khusus Olahragawan SMP/SMA Ragunan Jakarta”. Cakrawala Pendidikan, Juni 2011, Th. XXX, No 2. 
Afrizal. 2014. Metode Penelitian Kualitatif. Jakarta: Raja Grafindo Persada.

Aziz, Syamsir. 1999. Senam Dasar. DIP Proyek Universitas Negeri Padang.

Bompa, TO and Haff, GG. Periodization. 2009. Champaign, IL: Human Kinetics. Copyright. 2012 by the National Strenght and Conditioning Association. All rights reserved.

Damrah. 2015. "Evaluasi Program Sentra Pembinaan Tenis Sumatera Barat Dan Riau" Disertasi. Universitas Negeri Jakarta.

Djaali, Puji Mulyono dan Ramli. 2000. Pengukuran Dalam Bidang Pendidikan. Jakarta: PPS UNJ.

Yusuf, Farida. 2008. Evaluasi Program dan Instrumen Evaluasi Untuk Program Pendidikan dan Penelitian. Jakarta: Rineka Cipta.

Guili Zhang, Nancy Zeller, Robin Griffith, Debbie Metcalf dkk. 2011. "Using the Context, Input, Process, and Pruduct Evaluation Model (CIPP) as a Comprehensive Framework to Guide the Planning, Implementation, and Assessment of Service-learning Program". Journal of Higher Education Outreach and Engagement Volume 15 No 4. ISSN 1534-6104. Copyright by the University of Georgia.

Harsono. 2001. Coaching dan Aspek Psikologis dalam Coaching. Jakarta: CV. Tambak Kusuma.

Harsuki. 2012. Pengantar Manajemen Olahraga. Jakarta: Raja Grafindo Persada.

Hidayat, Imam. 1996. Teori Senam. Bandung: FPOK IKIP Bandung.

Firdaus, Kamal. 2011. "Evaluasi Program Pembinaan Olahraga Tenis Lapangan di Kota Padang". Jurnal Media Ilmu Keolahragaan Indonesia Volume 1. Edisi 2. Desember 2011. ISSN: 2088-6802.
Kirkpatrick D, L. \& Kirkpatrick, J.D. 2009. Evaluating Training Programs: the four levels 3rd ed. San Francisco: BerretKoehler Publishers, Inc.

Kumar Manish dan Ombir. "A comprehensive study of physical fitness components of artistic and rhythmic female gymnasts of Haryana". International Journal of Enhanced Research in Educational Development (IJERED), ISSN: 23208708.

Martens, Rainer. 2004. Successful Coaching 3rd Edition. Human Kinetics.

Moleong, J Lexy. 2007. Metodologi Penelitian Kualitatif. Bandung: Remaja Rosdakarya.

Nossek, Josef.1982. General Theory of Training. Lagos: Pan African Press,Ltd.

Pate Russel, Bruce Mc. Clenaghan, \& Robert Rotella. 1993. Dasar-Dasar Ilmiah Kepelatihan. Terjemahan Kasiyo Dwijowinoto, MS. Semarang. IKIP Semarang Press.

Stufflebeam, L Daniel. 2007. CIPP Evaluation Model Checklist. San Fransisco. Jossey Bass.

2017. The CIPP Evaluation Model. New York London. The Guilford Press.

Sudjana, Djudju. 2006. Evaluasi Program Pendidikan Luar Sekolah. Bandung: PT Remaja Rosdakarya.

Suharsimi, Arikunto. 2008. Evaluasi Program Pendidikan: Pedoman Teoritis Praktis Bagi Mahasiswa dan Praktisi Pendidikan (Edisi Kedua). Jakarta: Bumi Aksara.

Sugiyono. 2011. Metode Penelitian Pendidikan. Bandung : Alfabeta.

Syahara, Sayuti. 2011. Pertumbuhan \& Perkembangan Fisik Motorik. Padang. UNP Press. 
Syafruddin. 2013. Ilmu Kepelatihan Olahraga. (Teori dan Aplikasinya dalam Pembinaan Olahraga). Padang: UNP Press.

2012. Ilmu Kepelatihan Olahraga. UNP PRESS.

Tim Penyusun. 2016. Buku Panduan Penulisan Tesis Program Studi Pendidikan Olahraga S2. Padang : Program Studi Pendidikan Olahraga S2.

Prastati, Trini. 2011. "Program Evaluation On Tutor Training At Open University". Jurnal Evaluasi Pendidikan Vol. 2 No. 2, Oktober 2011, 206-217.

Kemenpora. 2015. Undang-Undang RI No. 3 Tahun 2005 tentang Sistem Keolahragaan Nasional. Kementerian Negara Pemuda dan Olahraga Republik Indonesia.

Wakhinuddin. 2009. Evaluasi Program. Padang. UNP Press.

Widoyoko, E. P. 2009. Evaluasi Program Pembelajaran: Panduan Praktis Bagi Pendidik Dan Calon Pendidik. Yogyakarta: Pustaka Belajar.

Zalfendi. 2016. "Evaluasi Penyelenggaraan Pusat Pendidikan Dan Latihan Olahraga Pelajar Provinsi Sumatera Barat Cabang Sepaktakraw Melalui Pendekatan CIPPO." Disertasi. Program Pascasarjana. Universitas Negeri Padang. 